\title{
THE MODERATING ROLE OF POWER CULTURE IN THE EFFECT OF DARK LEADERSHIP ON ORGANIZATIONAL ETHICAL CLIMATE
}

\author{
Erdinç BALLI ${ }^{1}$, Ayşe İpek KOCA BALLI ${ }^{2}$
}

\begin{tabular}{l} 
Article Info \\
\hline Araştırma Makalesi \\
DOI: $10.35379 /$ cusosbil.751017 \\
\hline Article History: \\
Received 11.06 .2020 \\
Revised $\quad 03.02 .2021$ \\
Accepted 11.03 .2021 \\
\hline Keywords: \\
Dark Leadership, \\
Ethical Climate, \\
Power Culture, \\
Hotel Enterprises.
\end{tabular}

\begin{abstract}
The aim of this study is to determine whether power culture plays a moderating role in the relationship of dark leadership with organizational ethical climate. The research was carried out in various 4 and 5 star hotel enterprises in the four metropolis of Turkey (İstanbul, Ankara, İzmir and Adana). Within the scope of the research, 794 surveys obtained from hotel employees were used. According to the research results; paranoid leadership $(B=-0,415 ; \mathrm{p}<0,05)$, narcissistic leadership $(\mathrm{B}=-0,059 ; \mathrm{p}<0,05)$, compulsive leadership $(B=-0,097 ; p<0,05)$ and passive-aggressive leadership $(B)=-$ $0,069 ; \mathrm{p}<0,05)$, which are the sub-dimensions of dark leadership, all have a negative effect on organizational ethical climate. However, power culture has been shown to play a moderating role in the effect of paranoid and passive-aggressive leadership on ethical climate.
\end{abstract}

\section{KARANLIK LİDERLİĞİ ÖRGÜTSEL ETİK İKLIMM ÜZERİNE ETKİSINNDE GÜC KÜLTÜRÜNÜN DÜZENLEYİCI ROLÜ}

\section{Makale Bilgisi}

Research Article

\begin{tabular}{lc} 
DOI: $10.35379 /$ cusosbil.751017 \\
\hline Makale Geçmişi: \\
Geliş & 11.06 .2020 \\
Düzeltme & 03.02 .2021 \\
Kabul & 11.03 .2021 \\
\hline
\end{tabular}

Anahtar Kelimeler:

Karanlık Liderlik,

Etik İklim,

Güç Kültürü,

Otel İșletmeleri.

\section{ÖZ}

$\mathrm{Bu}$ çalışmanın amacı, karanlık liderliğin örgütsel etik iklim ile ilişkisinde güç kültürünün düzenleyici bir rol üstlenip üstlenmediğini belirlemektir. Araştırma, Türkiye'nin dört büyük ili olan İstanbul, Ankara, İzmir ve Adana'da faaliyet gösteren 4 ve 5 yıldızlı otel işletmelerinde gerçekleştirilmiştir. Araştırma kapsamında otel çalışanlarından elde edilen 794 anket kullanılmıştır. Araştırma sonuçlarına göre; karanlık liderliğin alt boyutları olan paranoyak liderlik $(B=-0,415 ; p<0,05)$, narsis liderlik $(B=-0,059 ; \mathrm{p}<0,05)$, zorlayıcı liderlik $(B=-0,097 ; \mathrm{p}<0,05)$ ve pasif-agresif liderliğin $(B=-0,069 ; p<0,05)$ tümü, örgütsel etik iklim üzerinde negatif bir etkiye sahiptir. Bununla birlikte paranoyak liderlik ve pasif agresif liderliğin etik iklim üzerine etkisinde güç kültürünün, düzenleyici bir etkiye sahip olduğu görülmüştür.

\footnotetext{
${ }^{1}$ Asst. Prof., Cukurova University, Hospitality Management Department, eballi@cu.edu.tr, ORCID: 0000-0001-5111-1868

2 Asst. Prof., Cukurova University, The Faculty of Kozan Business Administration, Business Administration Department, ikocaballi@cu.edu.tr, ORCID:0000-0001-7808-5807

Alıntılamak için/Cite as:Ballı, E., Koca Ballı, A. İ. (2021), The Moderatıng Role of Power Culture in the Effect of Dark Leadership on Organizational Ethical Climate, Çukurova Üniversitesi Sosyal Bilimler Enstitüsü Dergisi, 30 (1), 22-33.
} 
Çukurova Üniversitesi Sosyal Bilimler Enstitüsü Dergisi, Cilt 30, Say1 1, 2021, Sayfa 22-33

\section{INTRODUCTION}

Hotel enterprises are labor-intensive organizations in which employees are highly effective in the organizational success. Since the role of the employee in the production and presentation process of the product is great in hotel enterprises, employee performance plays an important role in product quality perception. In this sense, it is important to know the concepts that play a role in employee performance and the factors that affect these concepts in order to increase product quality and organizational success.

Ethical climate is one of the variables that affect employee behavior and enable organizational results to be shaped in a positive or negative way (Martin \& Cullen, 2006). Organizational ethical climate can affect many organizational variables such as organizational commitment, job satisfaction, dedication, job performance, tendency to quit job and trust in the organization (Welsch \& La Van, 1981; Schwepker, Ferrel \& Ingram, 1997; Vardi, 2001; Jaramillo, et al., 2006). Many factors play a role in the formation of an ethical climate, which is related to the ethical procedures and policies that employees consider to exist in their organizations, and their perceptions that are permanent and psychologically meaningful. In particular, leaders are at the top of these factors. They can play a role in shaping the ethical climate within the organization with their behavior, rules, plans and policies. When the researches about leadership are analyzed, it is seen that the majority of them investigate the successful leadership and what are the factors that make the leader successful. However, the increase in the number of company scandals, ethical violations and failed organizations shows that the examination of the effects and consequences of a very important side - negative side - of the leadership is neglected. The studies on dark leadership look at the effects of leadership through an inverted perspective and deal with the negative side of the leader. Dark leadership can be defined as the negative characteristics of a leader's personality that affect his/her behavior and decisions, so the organization, in a negative way. Looking at the studies examining the effects of dark leadership on organizational outcomes, it has been revealed that dark leadership has a negative effect on task performance, contextual performance, general job performance (Moscoso \& Salgado, 2004; Torregiante, 2005; Benson \& Campbell, 2007) and organizational commitment (Gillaspie, 2009; Kayalar \& Arslan, 2011; Ballı \& Çakıc1, 2016), but a positive effect on tendency to quit job (Gillaspie, 2009; Tuna, Konaklığlu \& Kıanlıklı, 2010) and organizational silence (Ballı \& Çakıc1, 2016). Another important concept that affects employees and organizational life is organizational culture. It can also be regarded as an important factor in ensuring that the organizational objectives are understood well and treated properly by the employees (Boylu \& Sökmen, 2011). Organizational culture has a significant effect on many organizational elements as it guides the behavior of employees.

In this research, the main benefit of which is to contribute to the literature in the field of organizational ethical climate, leadership and organizational culture, it is aimed to examine the possible effect of dark leadership, which is accepted as one of the negative leadership types, on the ethical climate perception of employees and the moderating role of power culture in this effect. Although there are previous studies that dealt with these variables in binary, these three variables were handled together with this study for the first time. In this sense, it is a pioneer for the related literature. In addition, it is believed that this study will create awareness among practitioners and contribute to the development of organizational policies, strategies and plans, as well as providing significant benefits within the scope of creating an effective leadership, ethical climate and organizational culture and achieving goals.

\section{Dark Leadership}

The main subject of the dark leadership research is the reflection of the personality that a leader has and the dysfunctional traits - the dark side - in his/her personality on his/her behaviors. Dark leadership can be defined as the dark aspect in the leader's personality that appears unconsciously (Hogan \& Hogan, 2001, p. 4), when s/he is stressed due to internal or external factors, or in difficult and uncertain situations, and affects the decisions and behaviors of him/her negatively (Furnham \& Trickey, 2011, p. 516) and causes results incompatible with the needs of the organization and the followers.

McIntosh and Rima (1997) examined the dysfunctional behaviors caused by the dark side of the leader's personality, and as a result of the analysis, they collected these behaviors under five different types of dark leadership: narcissistic, paranoid, co-dependent, compulsive and passive-aggressive.

Narcissistic leaders are people who need to be admired, who are inadequate in understanding the feelings of others, and believe that they are special people equipped with special rights (Köroğlu \& Bayraktar, 2007, p. 96). Because they focus too much on their own goals, they do not care about the goals of others and they can sacrifice others for their own purposes (Morf \& Rhodewalt, 2001, p. 179). Therefore, they contradict in terms of sociality 


\section{Çukurova Üniversitesi Sosyal Bilimler Enstitüsü Dergisi, Cilt 30, Sayı 1, 2021, Sayfa 22-33}

and ethics. They generally compete with someone and are not afraid to use manipulative strategies to achieve their goals during this competition.

The main characteristic of paranoid leadership is that the leader has a constant skepticism and suspicion, has difficulty in establishing and maintaining close relationships and is distant to people (Sperry, 2003, p. 193). They think that everyone around them is unreliable and that they should always be prepared for an attack. With this way of thinking, they attribute different meanings to the behavior of other members of the organization, assume that there is cheating and lies behind the behaviors and they are afraid of everything and everyone (McIntosh \& Rima, 1997, p. 123).

The most important characteristics of co-dependent leaders are their lack of trust, high need of compassion and fear of using initiative. They are unable to decide on their own, and if they do not take plenty of advice and support from others, they have difficulty even in making their daily decisions. They are generally afraid of making mistakes (Gillaspie, 2009, p. 11) and avoid taking responsibility. This situation causes distrust, uncertainty, problems and indifference behaviors towards the future of the organization (Kesken \& Ayyıldız, 2011, p. 243).

Compulsive leaders are in perfectionist behavior, because they want to gain the appreciation of others by doing everything perfectly (McIntosh \& Rima, 1997, p. 106). Persistence, extreme regularity, meticulousness, indecision and rigidity are the main characteristics. They have an authoritarian attitude and pursue absolute power and authority. They are fixed-minded, prescriptive, and annoyingly meticulous. In the management process, they prefer excessive control and pay attention to focus on details for this purpose (McIntosh \& Rima, 1997, p. 106). They are very sensitive to social rules and do not tolerate violation of these rules.

Passive-aggressive leaders are complaining, angry and self-interested. They can manipulate events and show sudden emotions, impulsions and outbursts of anger. In general, they can behave in a way that is perceived as unsteady and strange by others (Gillaspie, 2009, p. 14). They react impulsively and unexpectedly to the events and display varying behaviors each time. - With all sorts of excuses, they often see someone else as the reason for their failure (McIlduff \& Coghlan, 2000, p. 717).

\section{Organizational Ethical Climate}

The concept of organizational ethical climate is generally expressed as the common perception of employees that the rules, policies and practices of organizations are ethical (Victor \& Cullen, 1988). Ethical climate can also be expressed as a type of business climate that includes the organization's policies, procedures and practices that have moral consequences (Mulki, Jaramillo \& Locander, 2009). Jaramillo, Mulki and Solomon (2006, p. 272) define the ethical climate as the individual's perception that the organization's current practices, procedures, norms and values have ethical content. Ethical climate helps the organization members in determining which topics are ethical and according to which criteria these issues will be understood, evaluated and resolved. Researches show that ethical climate perception is a strong variable that allows organizational results to be shaped in a positive or negative way (Martin \& Cullen, 2006). Employees develop a positive attitude towards organizations that have open standards in a way that will distinguish ethical and unethical behavior. (Trevino, Butterfield \& McCabe, 2001). The strong organizational ethical climate also affects the unity, solidarity and morale power of the organization (Mathieu \& Zajac, 1990; Dickson, Smith, Grojean \& Ehrhart, 2001).

\section{Power Culture}

Harrison (1972) and Handy (1985) defined the organizational culture with a model consisting of four subdimensions: "success, support, hierarchy and power". Power culture which is one of these types of organizational culture, is managed by a central power source such as owner or president and is mostly found in entrepreneurial organizations. Such organizations have minimal bureaucracy, so staff work with a few rules, policies and procedures (Kane-Urrabzo, 2006). Power culture is seen in organizations that are structured as pyramids or networks. Everything that happens in such organizations where the powers are gathered at the top and in one hand is under the knowledge and control of the management. In power culture, some people are dominant, others are obedient, and the social order has a relatively limited and stable formation based on authority loyalty (Pheysey, 1993). In power culture, the employee does his/her job with hope of reward, fear of punishment or personal loyalty to a strong individual (Handy, 1985). 


\section{Research Hypotheses}

There are different factors that affect the formation of an ethical climate within the organization. Leadership and leader behaviors are among the most important of these factors. Within the organization, followers can take the leader's behaviors as a role model, imitate them, and over time, these behaviors can be perceived as accepted behaviors within the organization. In addition, leaders' policies and practices shape the ethical climate and play an important role in determining whether the organization's existing ethical character is weak or strong (Wimbush, Shepard \& Markham, 1997). In this sense, in order to create an ethical climate in the organization, the leader should behave ethically and be a good ethical example to the members of the organization (Aronson, 2001, p. 245). In their work, Mayer, Kuenzi and Greenbaum (2010) stated that the leader has a role in the development of an ethical climate in the business and emphasized that the leader creates an ethical climate that facilitates ethical behavior through ethical practices, policies and procedures.

Dark leaders are people who serve themselves, deceive and exploit their followers. Husted (2008: 1). Frankenhauser (2009, p. 53) defined dark leadership as the interaction between the individual's dark side and the decisions s/he makes -as leader- by caring for his/her own interests rather than the interests of others and declared it unethical to pursue his/her own interests. Likewise, Bass (1999, p. 181) and Howell (1992, p. 43) mentioned that dark leaders behave unethically and identified leaders who are unethical as dark. In such leaders, there is little room for values such as moral sensitivity, moral judgement, moral motivation and moral action (Frankenhauser, 2009, p. 38). Dark leadership is often prone to illegal behavior. In dark leadership, leaders find it difficult to draw a precise line between unethical and ethical. They make it difficult to differentiate between crime and noncrime (Woods, 2007, p. 14). The unethical behavior of the leader in this way may cause these behavior patterns to take place within the organization and thus to decrease the ethical climate in the organization. In addition, studies in literature have revealed that the relationship between ethical climate and types of leadership that are considered positive, such as ethical leadership (Bilgen, 2014; Günel, Civelek \& Karabulut, 2015), instrumental leadership (Mulki, Jaramillo \& Locander, 2009), paternalist leadership (Erben \& Güneser, 2008; Ötken \& Cenkci, 2012; Cheng \& Wang, 2015), servant leadership (Topçu, Gürsoy \& Taşbaşı, 2013; Burton, Peachey \& Wells, 2016), charismatic leadership (Zehir et al. 2014), authentic leadership (Toker, 2015), transformational leadership (Sağnak, 2010), and value-centered leadership (Çiçek, 2016), is positively oriented. In this sense, it has been observed that positive leadership affects the perception of organizational ethics in a positive way, so, it is believed that dark leadership, which is defined by the characteristics that are not desired to be in a leader and lead to failure, and which is accepted as a negative leadership type, will decrease the perception of organizational ethical climate.

$\mathrm{H}_{1}$ : Dark leadership negatively affects the perception of organizational ethics.

$\mathrm{H}_{1 \mathrm{a}}$ : Paranoid leadership negatively affects the perception of organizational ethics.

$\mathrm{H}_{1 b}$ : Narcissistic leadership negatively affects the perception of organizational ethics.

$\mathrm{H}_{1 \mathrm{c}}$ : Compulsive leadership negatively affects the perception of organizational ethics.

$\mathrm{H}_{1 \mathrm{~d}}$ : Passive-aggressive leadership negatively affects the perception of organizational ethics.

In different organizational cultures, it was seen that the styles of leaders differ from each other. While the leader displays an attitude that listens to the opinions of the subordinates and takes them into consideration in the supoort culture, $\mathrm{s} / \mathrm{he}$ displays a behavior that both guides and encourages participation in the success culture. In the role culture, there is a leader who does what $\mathrm{s} / \mathrm{he}$ is authorized to do, while in power culture there is a leader who tells others what to do (Diana,1993). Therefore, leaders in organizations that adopt power culture are expected to be strong and know everything. Subordinates, on the other hand, are expected to be harmonious and willing in the face of the rules set by the leader (Harrison, 1990). However, trust and personal communication are important features in power culture. Therefore, employees are expected to have comments similar to that of the leader (Kane-Urrabzo). In this sense, in organizations where power culture is effective in which rules, policies and procedures are limited and the behavior or personality of the leader is more effective, the negative behavior of the leader is expected to increase the effect of organizational ethics.

$\mathrm{H}_{2}$ : Power culture has a moderating role in the effect of dark leadership on the perception of organizational ethics.

$\mathrm{H}_{2 \mathrm{a}}$ : Power culture has a moderating role in the effect of paranoid leadership on the perception of organizational ethics. 


\section{Çukurova Üniversitesi Sosyal Bilimler Enstitüsü Dergisi, Cilt 30, Sayı 1, 2021, Sayfa 22-33}

$\mathrm{H}_{2 \mathrm{~b}}$ : Power culture has a moderating role in the effect of narcissist leadership on the perception of organizational ethics.

$\mathrm{H}_{2 \mathrm{c}}$ : Power culture has a moderatingrole in the effect of compulsive leadership on the perception of organizational ethics.

$\mathrm{H}_{2 \mathrm{~d}}$ : Power culture has a moderating role in the effect of passive-aggressive leadership on the perception of organizational ethics.

\section{METHOD}

Relational screening model was adopted in the research. The data needed to achieve the determined purpose was collected through the survey method. The survey form consists of four sections. In the first section, there is a "Dark Leadership Scale" consisting of 25 items and 5 sub-dimensions developed by Gillaspie (2009). In the second section, the items of power culture in the "Organizational Culture Type Scale (OCTS)" consisting of 16 items and 4 sub-dimensions that Mamatoğlu (2004) developed by modeling Harrison (Harrison, 1972; Harrison \& Stokes, 1992) and Handy's (1993) four-dimensional organizational culture typing that consists of "hierarchy, success, strength and support" sub-dimensions. Power culture in this scale is measured with 4 items. In the third section, "Organizational Ethical Climate Scale" consisting of 7 items and one dimension developed by Schwepker (2001) was used and the response categories of the items in all scales were subjected to 5-point Likert type. Response categories are scored as "(1) strongly disagree, (2) disagree, (3) indecisive, (4) agree, (5) strongly agree". In the fourth section, questions about the demographic characteristics of the participants are included.

The employees in 4 and 5 star hotel enterprises in the four metropolis of Turkey (İstanbul, Ankara, İzmir and Adana) constituted the universe of the research. The surveys were applied face-to-face or with drop-and-collect techniques between the dates May 2017 and June 2017. As a result of the implementation, 822 surveys were collected and it was seen that 794 of them were filled in accordance with the analysis. In this sense, the sample of this study consists of 794 hotel employees who filled the survey in accordance with the analysis. By using the SPSS 12.0 program, factor analysis, reliability analysis, correlation analysis, and Moderated Multiple Regression analysis were applied to the data collected from the sample.

\section{Validity and Reliability of the Scales}

In the study, exploratory factor analysis was performed in order to measure the construct validity of the scales. According to the results of the factor analysis, it was seen that the dark leadership scale, unlike the original scale, constitutes four sub-dimensions as passive-aggressive leadership, narcissistic leadership, paranoid leadership, and compulsive leadership. On the other hand, it was determined that the organizational ethical climate and power culture scales constitute a one-dimensional structure in parallel with the original structures. Crombach's Alpha values were evaluated for the reliability of the scales and this values were found to be, 847 for the whole dark leadership scale, $847,, 843$ for paranoid leadership,, 810 for narcissistic leadership,, 749 for compulsive leadership, ,676 for passive-aggressive leadership, ,760 for ethical climate, and ,783 for power culture. The analyzes were continued through these dimensions.

\section{FINDINGS}

The remarkable points about the demographic characteristics of the participants are as follows: $58,4 \%$ are male, $63,7 \%$ are lower-level employees, $32,2 \%$ are between the ages of $35-44$ and $44,1 \%$ are undergraduate.

In order to examine the relationship between variables, correlation analysis was conducted. Significant negative relationships were found between organizational ethical climate and paranoid leadership $(r=-0.487, p$ $<0.01)$, narcissistic leadership $(r=-0.095, p<0.01)$, compulsive leadership $(r=-0.152, p<0.01)$ and passiveaggressive leadership $(r=-0,102, p<0.05)$. Finally, a significant relationship was found between narcissistic leadership and power culture $(\mathrm{r}=0.94, \mathrm{p}<0.01)$. However, there is no significant relationship between power culture and ethical climate $(\mathrm{p}>0.05)$.

The results and model fit statistics of the regression analysis in which dark leadership (paranoid, narcissistic, compulsive, passive-aggressive) is taken as an independent, power culture as a moderating and organizational ethical climate as a dependent variable are presented in Table 1. In the first hypothesis (H1), the effect of dark leadership (independent variable)on the organizational ethical climate (dependent variable) was investigated and it was observed that paranoid leadership $(B=-0.415 ; p<0.05)$, narcissistic leadership $(B=-0.059 ; p<0.05)$, compulsive leadership $(B=-0.097 ; p<0.05)$ and passive-aggressive leadership $(B=-0.069 ; p<0.05)$ affect the 
Çukurova Üniversitesi Sosyal Bilimler Enstitüsü Dergisi, Cilt 30, Say1 1, 2021, Sayfa 22-33

organizational ethical climate in a negative way. In this sense, H1a, H1b, H1c, H1d hypotheses were all accepted.

Table 1. The Moderating Role of Power Culture in the Effect of Dark Leadership on Organizational Ethical Climate

\begin{tabular}{|c|c|c|c|c|c|c|c|c|c|c|}
\hline \multirow{2}{*}{ Steps } & \multirow{2}{*}{ Variables } & \multicolumn{5}{|c|}{ Regression Coefficients } & \multicolumn{4}{|c|}{ Model Statistics } \\
\hline & & $\mathrm{B}$ & S.H. & $\beta$ & $\mathrm{T}$ & $\mathrm{p}$ & $\mathrm{R}$ & $\mathrm{R}^{2}$ & $\mathrm{~F}$ & $\mathrm{p}$ \\
\hline 1 & Paranoid &,- 415 &, 026 &,- 489 & $-15,758$ &, 000 &, 489 & 239 & 248,312 &, 000 \\
\hline \multirow{2}{*}{2} & Paranoid &,- 416 & ,026 &,- 489 & $-15,768$ & ,000 & \multirow{2}{*}{,489 } & \multirow{2}{*}{,239 } & \multirow{2}{*}{124,313} & \multirow{2}{*}{, 000} \\
\hline & Power &,- 012 &, 018 &,- 021 &,- 691 & ,490 & & & & \\
\hline \multirow{3}{*}{3} & Paranoid &,- 423 & ,026 &,- 498 & $-16,113$ &, 000 & \multirow{3}{*}{, 501} & \multirow{3}{*}{, 251} & \multirow{3}{*}{88,347} & \multirow{3}{*}{, 000} \\
\hline & Power &,- 009 &, 018 &,- 015 &,- 485 & 628 & & & & \\
\hline & Interaction &,- 053 &, 015 &,- 110 & $-3,568$ &, 000 & & & & \\
\hline 1 & Narcissistic &,- 059 &, 022 &,- 095 & $-2,690$ & ,007 &, 095 &, 009 & 7,234 &, 007 \\
\hline \multirow{2}{*}{2} & Narcissistic &,- 060 & ,022 &,- 096 & $-2,701$ & ,007 & \multirow{2}{*}{,096 } & \multirow{2}{*}{,009 } & \multirow{2}{*}{3,648} & \multirow{2}{*}{, 026} \\
\hline & Power &,- 005 &, 020 &,- 009 &,- 266 & ,791 & & & & \\
\hline \multirow{3}{*}{3} & Narcissistic &,- 061 &, 022 &,- 097 & $-2,721$ & ,007 & \multirow{3}{*}{0,96} & \multirow{3}{*}{,009 } & \multirow{3}{*}{2,475} & \multirow{3}{*}{, 060} \\
\hline & Power &,- 005 & ,020 &,- 009 &,- 259 & ,796 & & & & \\
\hline & Interaction &,- 007 &, 019 &, 013 &,- 371 &, 710 & & & & \\
\hline 1 & Compulsive &,- 097 &, 023 &,- 152 & $-4,320$ &, 000 &, 152 &, 023 & 18,664 &, 000 \\
\hline \multirow{2}{*}{2} & Compulsive &,- 097 &, 023 &,- 152 & $-4,318$ &, 000 & \multirow{2}{*}{, 152} & \multirow{2}{*}{,023 } & \multirow{2}{*}{9,321} & \multirow[b]{2}{*}{, 000} \\
\hline & Power &, 001 &, 020 &, 001 &, 034 & ,973 & & & & \\
\hline \multirow{3}{*}{3} & Compulsive &,- 097 & ,023 &,- 152 & $-4,313$ &, 000 & \multirow{3}{*}{, 152} & & & \\
\hline & Power &, 000 & ,020 &, 001 & ,022 & ,982 & & ,023 & 6,235 &, 000 \\
\hline & Interaction & ,006 &, 020 &, 010 & ,292 & ,770 & & & & \\
\hline 1 & Pas.-Agr. &,- 069 &, 024 &,- 102 & $-2,878$ & ,004 &, 102 &, 010 & 8,282 &, 004 \\
\hline 2 & Pas.-Agr &,- 069 & ,024 &,- 102 & $-2,876$ & ,004 & 102 & 010 & 4136 & 016 \\
\hline 2 & Power &, 001 &, 020 &, 001 &, 031 & ,975 &, 102 & ,010 & 4,156 & ,010 \\
\hline & Pas.-Agr &,- 068 & ,024 &,- 100 & $-2,826$ & ,005 & & & & \\
\hline 3 & Power &, 003 & ,020 & ,006 & , 160 & ,873 & , 129 & ,017 & 4,424 & ,004 \\
\hline & Interaction &,- 047 & ,021 &,- 079 & $-2,227$ & ,026 & & & & \\
\hline
\end{tabular}

In the second hypothesis $\left(\mathrm{H}_{2}\right)$, it was investigated whether power culture has a moderating role on the effect of dark leadership on the organizational ethical climate. Accordingly, the interaction between paranoid leadership and power culture $(\mathrm{B}=-0.053 ; \mathrm{p}<0.05)$ and the interaction between passive-aggressive leadership and power culture $(\mathrm{B}=0.047 ; \mathrm{p}<0.05)$ were found to be significant on the organizational ethical climate. However, the interaction between narcissistic leadership and power culture $(\mathrm{B}=-0.007 ; \mathrm{p}>0.05)$ and the interaction between compulsive leadership and power culture $(B=-0.006 ; p>0.05)$ were found to be insignificant on the organizational ethical climate. In this sense, it is understood that power culture has a moderating role in the effect of paranoid and passive-aggressive leadership on the organizational ethical climate. As a result, $\mathrm{H}_{2 \mathrm{a}}$ and $\mathrm{H}_{2 \mathrm{~d}}$ hypotheses were accepted, but $\mathrm{H}_{2 \mathrm{~b}}$ and $\mathrm{H}_{2 \mathrm{c}}$ hypotheses were rejected.

The effect of low and high level (in cases where there is a power culture in the standard deviation of +1 and 1 from its mean value) of paranoid leadership and passive aggressive leadership tendency on the organizational ethical climate is graphically shown in Figure 1 and Figure 2 to determine the form and direction of the interaction between paranoid and passive-aggressive leadership and power culture.

Whether the slope in Figure 1, which shows the relationship between low and high level of power culture in the organization and low and high level of paranoid leadership, was significantly different from 0 (null), was analyzed with slope test (Aiken and West, 1991). This test reveals whether the relationship between paranoid leadership and ethical climate depends on the level of power culture in the organization. Figure 1 shows that paranoid leadership and power culture have an interactive effect on the ethical climate. For situations where the level of power culture is low and high, the relationship between paranoid leadership and ethical climate is meaningful and negative, but the strength of this negative relationship is greater in high level of power culture. According to these results, the relationship between paranoid leadership and ethical climate is shaped by power culture. As paranoid leadership increases both in low and high level of power culture, ethical climate perception decreases. This decrease is likely to be greater in a high level of power culture. 
Çukurova Üniversitesi Sosyal Bilimler Enstitüsü Dergisi, Cilt 30, Sayı 1, 2021, Sayfa 22-33

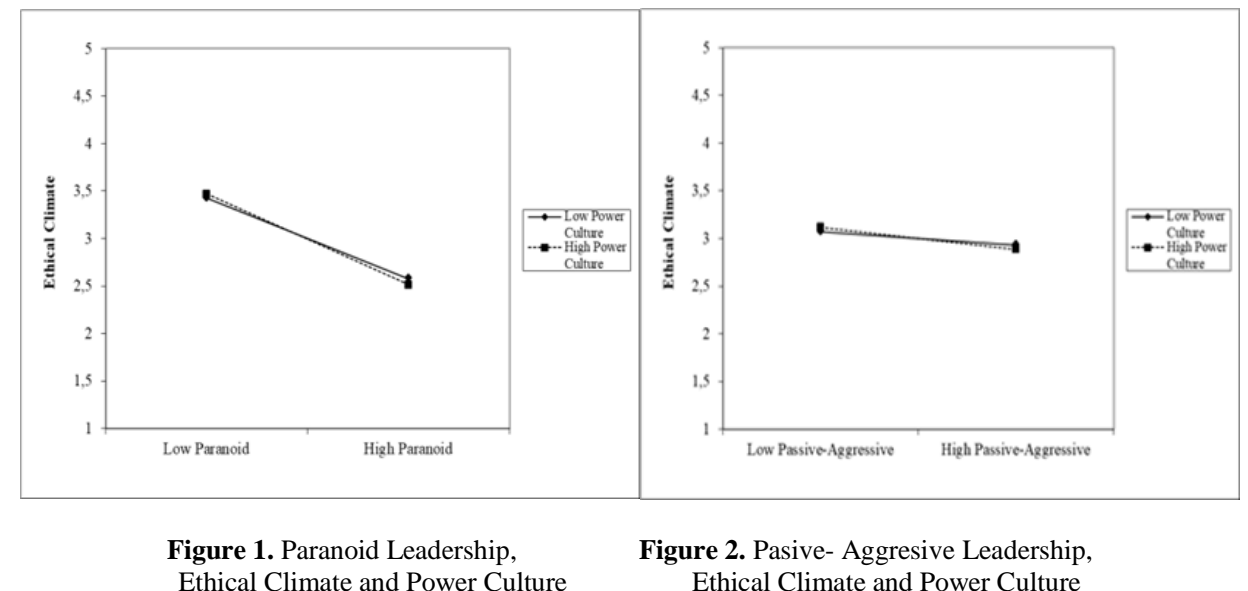

In Figure 2, it is seen that paranoid leadership and power culture have an interactive effect on the ethical climate. In cases where power culture is low, there is not much change in ethical climate perception, whereas in high power culture this perception decreases. Therefore, in organizations with high level of power culture, the level of passive-aggressive leadership that decreases the perception of ethical climate is higher.

\section{RESULT}

In this research, the variables of leadership, ethical climate and organizational culture, which have direct or indirect effects on employees' organizational behavior and performance, were investigated specifically for hotel enterprises. The moderating role of organizational culture in the relationship between leadership and ethical climate was tried to be explained by the models created within the scope of the determined sample. Dark leadership, which is considered negative as the leadership type, and power culture, as the organizational culture, were used.

When the effect of dark leadership on ethical climate perception was examined, it was seen that all dark leadership types have an effect on the ethical climate perception and this effect is negative. In this sense, the $\mathrm{H}_{1}$, $\mathrm{H}_{1 \mathrm{a}}, \mathrm{H}_{1 \mathrm{~b}}, \mathrm{H}_{1 \mathrm{c}}$ and $\mathrm{H}_{1 \mathrm{~d}}$ hypotheses of the research were accepted. In the literature review conducted to compare these findings, no study examining the effect of dark leadership, which is seen as a negative type, on the ethical climate, was found. However, when looking at leadership from a reverse perspective, it can be said that the results of this study support the results of studies (Güneser, 2008; Locander, 2009; Sağnak, 2010; Erben, Ötken \& Cenkci, 2012; Topçu, Gürsoy \& Taşbaş1, 2013; Bilgen, 2014; Zehir et al., 2014; Günel, Civelek \& Karabulut, 2015 ; Mulki, Jaramillo \& Cheng \& Wang, 2015; Burton, Peachey \& Wells, 2016; Toker, 2015; Flower, 2016) that demonstrate that leadership types, which are seen as positive, affect the ethical climate in a positive way. In this context, it can be said that dark leadership generally affects the organizational ethical climate in a negative way.

In the next section of the study, the power culture variable was included as a moderator to determine whether power culture plays a moderating role in the effect of dark leadership on the organizational ethical climate. As a result of the analyzes, it was seen that power culture may play a moderating role in the effect of paranoid and passive-aggressive leadership on the ethical climate. In organizations with high level of power culture, the decresing effect of paranoid and passive-aggressive leadership on the ethical climate is higher than in organizations with low level of power culture. In this sense, it can be said that the negative effect of dark leadership on the ethical climate in organizations with high level of power culture increase. Therefore, $\mathrm{H}_{2}, \mathrm{H}_{2 \mathrm{a}}$ and $\mathrm{H}_{2 \mathrm{~d}}$ hypotheses of the research were accepted, but $\mathrm{H}_{2 \mathrm{~b}}$ and $\mathrm{H}_{2 \mathrm{c}}$ hypotheses were rejected. In line with these findings, it can be said that dark leadership is a variable that decreases the organizational ethical climate, and in cultures where the level of power culture is high, the effect of dark leadership decreasing the ethical climate increases even more. Therefore, blocking dark leadership in organizations will prevent the decrease of organizational ethical climate. In addition, it is important for the ethical climate to create a low level of power culture in organizations with dark leaders. In this context, based on the research findings and the literature, some suggestions were made to the practitioners about how the dark side in the leader can be managed and how the negative effects within the organization can be prevented. The dark side is not a mental illness, it is the defects 


\section{Çukurova Üniversitesi Sosyal Bilimler Enstitüsü Dergisi, Cilt 30, Say1 1, 2021, Sayfa 22-33}

that hinder the manager in his/her strategies to form a team, shape his/her collaborations and achieve plans, visions and goals. The dark side of personality is present -more or less- in everyone. The important thing is to be aware of this side and able to manage it. Both leaders, their followers, and the top management of the organization need to be aware that this dark side may exist, identify what these possible aspects are and try to manage them. The leader plays an important role in determining and managing the dark side. Leaders are generally able to resist accepting the existence of the dark side and choose the denial method. For leaders, the best way to discover their dark side is to ask the people they have relationships with. Their families, colleagues, subordinates, and superiors are some of these people. They can best understand and say how the leader behaves in times of stress and fatigue. In this sense, leaders should ask them their opinions and impressions about their behavior. Another method that leaders can use to identify their dark sides is the dark leadership tests created in this regard. By applying these tests to themselves, they can determine which kind of dark leadership they are capable of, and the size of this capability, and they can work on this.

Another important point is that leaders receive external support in order to prevent and manage the dark side. One of the external supports is that the leader receives support and / or training from a specialist. In this regard, a leader can receive "coach" support and participate in relevant trainings. Since personality traits play an important role in dark leadership behaviors, personality traits scales should be used in the election of managers or candidates of manager for organizations. In addition, in order to recognize and work on dark leadership behaviors in enterprises, it is recommended that senior managers regularly hold information meetings to be prepared with human resources and communication specialists together, without discrimination between managers and non-managers. It is very important that the culture, policies and communication channels within the organization are suitable for feedback. Organizational conditions can also trigger dark leadership. In organizations, the distribution of power needs to be well adjusted. In organizations where job descriptions, goals, methods of achieving the goals, authorization and responsibilities are not determined, individuals can more easily tend to wrong and perverted behaviors to achieve their own interests and goals. In this sense, authority, responsibilities, job description, work flows and methods, reward-penalty mechanism within organizations should be well defined and implemented. Especially in the organizations where the control mechanism is working in a poor way, the behavior is less controlled, so the individual pays less attention to his/her behaviors (Gillaspie, 2009, p. 22). In cases where the leaders' behaviors and decisions are uncontrollable and unanswerable, they can act more comfortably and fearlessly in line with their own interests and goals. In this sense, it should be ensured that control mechanisms within organizations are always well operated.

When the related literature is analyzed, it is seen that both the relationship between dark leadership and ethical climate and the role of power culture in this relationship were handled for the first time with this study. It is thought that this study is a pioneer and will contribute to the related literature. In this sense, repeating the results of this research, which examines the variables of dark leadership, ethical climate and organizational culture, with studies to be carried out by different researchers, is important in terms of the reliability of the findings between the variables. This study was performed in the sample of service sector and hotel enterprises. Comparing the results of later studies in different sectors is important for evaluating possible sectoral differences. Within the scope of the study, only the moderating role of power culture among the organizational cultures was examined. In future studies, it is suggested that other types of culture should be included in the research and their mediating roles should be examined as well as their moderating roles. In this study, organizational ethical climate was measured with its one-dimensional structure. However, there are scales in the literature that measure ethical climate perception with their multi-dimensional structures. In future studies, the effects of dark leadership and its sub-dimensions on the sub-dimensions of the ethical climate can also be examined. One of the important issues affecting the measurement and evaluation of employee perceptions is the role of the national culture. The sample of this study generally consists of employees who belong to the Turkish culture. It is important to carry out further studies on employees with different nationalities and cultures and to compare the results to determine whether the perception of dark leadership, ethical climate and organizational culture differs according to national cultures. It should be noted that this study not only provides important information to the literature and practitioners but also includes various limitations. The facts that the data used in this research was collected by the survey technique and the possibility of the opinions and ideas of the participants were reflected in the data constitute a limitation for the research. The research was carried out only with the participation of 4 and 5 star hotel employees in four cities due to financial and temporal constraints. For this reason, it can be said that future studies that will be performed with the inclusion of hotels in all provinces and all star categories can create different perspectives. 
Çukurova Üniversitesi Sosyal Bilimler Enstitüsü Dergisi, Cilt 30, Sayı 1, 2021, Sayfa 22-33

\section{REFERENCES}

Ballı E. \& Çakıcı A. (2016). Karanlık liderliğin örgütsel bağlılık ve örgütsel sessizlik üzerine etkisi: otel çalışanları üzerinde bir araştırma. Çukurova Üniversitesi Sosyal Bilimler Enstitüsü Dergisi, 25, 167180.

Bass, BM (1999). Ethics, character, and authentic transformational leadership. Leadership Quarterly, $10(2), 181$.

Benson, MJ \& Campbell, JP (2007). To be or not to be linear: an expanded representation of personality and its relationship to leadership performance. International Journal of Selection and Assessment, 15(2), 232249.

Bilgen, A. (2014). Çalışanların etik liderlik ve etik iklim algılamalarının örgütsel bağlılıklarına etkisi: özel ve kamu sektöründe karşılaştırmalı bir uygulama [Yayımlanmamış Yüksek Lisans Tezi, Bahçeşehir Üniversitesi].

Boylu, Y., \& Sökmen, A. (2006). Konaklama işletmelerinde örgüt kültürünün tespit edilmesi: Ankara ilinde faaliyet gösteren beş yıldızlı otel işletmeleri üzerine bir uygulama. Sosyal Ve Beşeri Bilimler Araştırmaları Dergisi, (17).

Burton, LJ, Peachey, JW. \& Wells, JE (2016). The role of servant leadership in developing an ethical climate in sport organizations. Journal of Sport Management, 1-37.

Cheng, MY \& Wang, L. (2015). The mediating effect of ethical climate on the relationship between paternalistic leadership and team identification: A team-level analysis in the Chinese context. Journal Of Business Ethics, 129(3), 639-654.

Conger, JA (1990) The dark side of leadership. Organisation Dynamics, 19(2), 44-55.

Cullen, JB, Victor, B. \& Stephens, C. (1989). An Ethical Weather Report: Assessing the Organization's Ethical Climate, Organizational Dynamics, 18(2), 50-62.

Çiçek, B. (2016). Değer merkezli liderliğin etik iklim ve çalışan sesi üzerindeki etkisi [Yayımlanmamış Doktora Tezi, İnönü Üniversitesi].

Deal, TE, \& Kennedy, AA (1982). Corporate cultures: The rites and rituals of corporate life. Reading, AddisonWesley Publishing Co, Mass.

Denison, DR \& Mishra, AK (1995). Toward a theory of organizational culture and effectiveness. Organization Science, 6(2), 204-223.

Deshpande, R. \& Webster FE (1993). Organizational culture and marketing: defining the research agenda. Journal of Marketing, 53, 3-15.

Dickson, M., Smith MW, Grojean MC \& Ehrhart MW (2001). An organizational climate regarding ethics: the outcome of leader values and the practices that reflect them. Leadership Quarterly. 12, 197-214.

Erben, GS, \& Güneser, AB (2008). The relationship between paternalistic leadership and organizational commitment: Investigating the role of climate regarding ethics. Journal of Business Ethics, 82, 955968.

Frankenhauser PT (2009). An investigation of the relationship between dark leadership and the effectiveness of transformational leadership in law enforcement. Unpublished doctoral dissertation, Capella University, USA. 
Çukurova Üniversitesi Sosyal Bilimler Enstitüsü Dergisi, Cilt 30, Say1 1, 2021, Sayfa 22-33

Furnham A. \& Trickey, G. (2011). Sex differences and dark side traits. Personality and Individual Differences, 50, 517-522.

Gillaspie, SM (2009). The impact of dark leadership on organizational commitment and turnover [Unpublished Master Thesis].

Grojean, MW, Resick, CJ, Dickson, MW \& Smith, DB (2004). Leaders, values, and organizational climate: Examining leadership strategies for establishing an organizational climate regarding ethics. Journal Of Business Ethics, 55(3), 223-241.

Günel, D., Civelek, ME, \& Karabulut, T. (2015). İşletmelerde etik liderliğin etik iklim üzerine etkisi: Deneysel bir araştırma. İstanbul Ticaret Üniversitesi Sosyal Bilimler Dergisi, 14 (28), 251.

Handy, CB (1985), Understanding Organizations, 3rd ed.,Penguin.

Harrison, B. (ed.) (1990) Culture and the Language Classroom. Modern English Publications.

Harrison R. \& Stokes, H. (1992). Diagnosing organization culture. Pfeiffer and Company.

Hitt, WD (1990). Ethics and Leadership: Putting Theoryinto Practice. OH: Batelle Press.

Hofstede, G. (1980). Culture's consequences: international differences in work-related values. Beverly Hills, CA: Sage Publications.

Hofstede, G. (2001). Culture's consequences: Comparing values, behaviors, institutions and organizations across nations, 2.Edition. Sage.

Hogan, R. \& Hogan, J. (1997). Hogan development survey manual. Hogan Assessment Systems.

Hogan, R., \& Hogan, J. (2001). Assessing leadership: A view of the dark side. International Journal of Evaluation and Assessment, 9, 40-51.

Howell, J. (1992). The ethics of charismatic leadership: submission or liberation. Academy of Management Executive, 6(2), 43.

Husted CL (2008). Systematic differentıatıon between dark and light leaders: is a corporate criminal profile possible?. Unpublished doctoral dissertation, Capella University, USA.

Jaramillo, F., Mulki, JP \& Solomon, P. (2006). The Role of ethical climate on salespersones role stress, job attitudes, turnover intention, and job performance. Journal of Personel Selling \& Sales Management, 26 (3), 271- 282.

Kane-Urrabzo C. (2006). Management's role in shaping organizational culture. Journal of Nursing Management, 14, 188-194.

Kayalar M., \& Arslan ET (2011). Karanlık liderliğin örgütsel bağlllı̆ga etkisi: Isparta perakende sektöründe bir araştırma. Çanakkale Üniversitesi 19. Ulusal Yönetim ve Organizasyon Kongresi, 410-414, Çanakkale.

Kesken, J. \& Ayyıldız, NA (2011). Öteki liderlik. Gazi Kitabevi.

Klenke, K. (2007). Authentic leadership: A self, leader, and spiritual identity perspective. International Journal of Leadership Studies, 13(1), 68- 97.

Köroğlu, E. \& Bayraktar, S. (2007). Kişilik bozuklukları. HYB Yayıncılık. 
Çukurova Üniversitesi Sosyal Bilimler Enstitüsü Dergisi, Cilt 30, Sayı 1, 2021, Sayfa 22-33

Mamatoğlu, N. (2004). Örgütsel kültür tipi ölçeği. Psikiyatri Psikoloji Psikofarmoloji Dergisi. 12(4), 305-315.

Martin, KD \& Cullen, JB (2006). Continuities and Extensions of Ethical Climate Theory: A Meta-Analytic Review. Journal of Business Ethics, 69, 175- 194.

Mathieu, JE, \& Zajac, DM (1990). A review and meta-analysis of the antecedents, correlates, and consequences of organizational commitment. Psychological Bulletin, 108, 171-194.

Mayer, DM, Kuenzi, M., \& Greenbaum, RL (2010). Examining the link between ethical leadership and employee misconduct: The mediating role of ethical climate. Journal of Business Ethics, 95, 7-16.

McIntosh, G. \& Rima SD (1997). Overcoming the dark side of leadership-the paradox of personal dysfunction. Grand Rapids, MI: Baket Books.

Morf, CC \& Rhodewalt, F. (2001). Unraveling paradoxes of narcissism: A dynamic self-regülatory processing model. Psychological Inguiry, 12,177-196.

Moscoso, S., \& Salgado, J. (2004). Dark side personality scales as predictors of task, contextual, and job performance. International Journal of Selection and Assessment, 12, 356-362.

Mulki, J., Jaramillo, J. \& Locander, W. (2009). Critical role of leadership on ethical climate and salesperson behaviors. Journal of Business Ethics, 86(2), 125-141.

Ötken A. \& Cenkci, T. (2012). The Impact of Paternalistic Leadership on Ethical Climate: The Moderating Role of Trust in Leader. Journal of Business Ethics, 108 (4), 525-536.

Özdemir, E. (2003). Liderlik ve etik. Uludă̆ Üniversitesi İktisadi ve İdari Bilimler Fakültesi Dergisi, 22(2), 151-168.

Özgener, Ş., (2004). İ̧ ahlakının temelleri-yönetsel bir yaklaşım, Nobel.

Pheysey, DC (1993). Organisational cultures. Routledge.

Sagnak, M. (2010). The relationship between transformational school leadership and ethical climate. Educational Sciences: Theory and Practice, 10 (2), 1135-1152.

Schwartz, H \& Davis, S. (1981). Matching corporate culture to business strategy. Organizational Dynamics, 3048.

Schwepker, CH (2001). Ethical climate's relationship to job satisfaction, organizational commitment, and turnover intention in the salesforce. Journal of Business Research, 54 (1), 39-52.

Schwepker, CH, Ferrel, OC \& Ingram, TN (1997). The influence of ethical climate and ethical conflict on role stress in the sales force. Journal Of The Academy Of Marketing Science, 25(2), 99-108.

Taşçığlu, H. (2010). Yerel yönetimlerde örgüt kültürünün örnek olay kapsamında değerlendirilmesi. Dumlupınar Üniversitesi Sosyal Bilimler Dergisi, (28), 81-96.

Toker, ME (2015). Tepe yöneticinin otantik ve etik liderlik davranışlarının etik iklim algısına etkisi ve bir araştırma [Yayımlanmamış Yüksek Lisans Tezi, Toros Üniversitesi]. 
Çukurova Üniversitesi Sosyal Bilimler Enstitüsü Dergisi, Cilt 30, Say1 1, 2021, Sayfa 22-33

Topçu, MK, Gürsoy A. \& Taşbaşı, B. (2013). Etik iklim algısının bireysel yenilikçilik davranışlarına etkisinde hizmetkar liderliğin rolü. 21. Ulusal Yönetim ve Organizasyon Kongresi Bildiriler Kitabı, Nobel Yayınevi, 612- 617.

Torregiante, J. (2005). Destructive personality traits and leadership performance: A pattern-oriented approach [Unpublished Doctoral Dissertation, North Carolina State University].

Trevino, LK, Butterfield, KD \& McCabe, DL (1998). The ethical context in organizations: Influence on employee attitudes and behaviors. Business Ethics Quarterly, 8(3), 447-476.

Trompenaars, JC (1994). Riding the Waves of Culture. Irwin Publications.

Tuna, M., Konaklığlu, E., \& Kızanlıklı, M. (2010). Karanlık liderliğin çalışanların işten ayrılma eğilimine etkisi. Çukurova Üniversitesi 18. Ulusal Yönetim ve Organizasyon Kongresi, 619- 629, Adana.

Vardi, Y. (2001). The effects of organizational and ethical climates on misconduct at work, Journal of Business Ethics. 29(4), 325-337.

Victor, B. \& Cullen, JB (1988). The organizational bases of ethical work climates. Administrative Science Quarterly, 33(1), 101-125.

Welsch, HP, \& LaVan, H. (1981). Inter-relationships between organizational commitment and job characteristics, professional behavior, and organizational climate. Human Relations, 34, 1079-1089.

Wimbush, JC, Shepard JM \& S. E. Markham. (1997).An Empirical Examination of the relationship between Ethical Climate and Ethical behavior from Multiple Levels of Analysis. Journal of Business Ethics, 16 (16), 1705-1716.

Woods, MG (2007). The dark side of leadership: personal dysfunction or societal crisis? [Unpublished Doctoral Dissertation, Capella University].

Zehir, C., Müceldili, B., Altindağ, E., Şehitoğlu, Y., \& Zehir, S. (2014). Charismatic leadership and organizational citizenship behavior: The mediating role of ethical climate. Social Behavior And Personality: An International Journal, 42(8), 1365-1375. 